\title{
Improving Non-Locomotor Movement Through Instructional Leadership Metode In Retarded Children
}

\author{
Surohmat $^{1}$, Eko Purnomo ${ }^{2}$, Eddy Marheni ${ }^{3}$ \\ ${ }^{1}$ Universitas Negeri Padang, padang, indonesia (surohmat100498@gmail.com) \\ ${ }^{2}$ Universitas Negeri Padang, padang, indonesia (ekopurnomo@fik.unp.ac.id) \\ ${ }^{3}$ Universitas Negeri Padang, padang, indonesia(eddymarheni@ fik.unp.ac.id)
}

\begin{abstract}
This study uses a qualitative method, with data collection methods using interviews and observations, The application of the researcher collects retarded children and then gives direction regarding the implementation of the correct heating movement which starts from head to foot. This research was conducted on July 20 - September 252018 at Padang Perwari Special School, Sumatera Barat. The informants in this study were teachers who taught at an extraordinary school in Padang Perwari which amounted to 3 people, with research subjects amounting to 30 mentally disabled students. In this research treatment, learning is done using the Instructional Leadership method. The researchers' preliminary findings indicate several problems regarding non-locomotor motion in mentally retarded children. Then the form of completion is given by using the Instructional Leadership method and the result is an increase and ease of student learning in carrying out nonlocomotor movements.
\end{abstract}

Keyword: Retarded, Non-Locomotor, Instructional Leadership

\section{Introduction}

In the 1945 Constitution article 31 paragraph 1, the government affirms that every citizen has the right to education. Then in article 5 of the National Education System Law states that "Every citizen has the same rights to get education" (Yuniar Indah Utari dan Nanik Indahwati. 2015). Education is a human need, not only are they normal, but also those who are disabled / children with special needsThe rights to get education for $\mathrm{ABK}$ are included in the Education for All framework, include, among others: every child has a fundamental right to education every child has characteristics, interest, ability, and unique learning needs (Gunarhadi dan Esti Wardani. 2011).

Education is a natural process that takes place naturally in human life in society. In the development of this process can take place in a family environment, 
school, and society. Understanding education in the national education system is an attempt to prepare students through the teaching and learning process (Gurit Prastowo dan Abdul Rachman Syam. 2014). Education is a very important activity to prepare students as students to face their future lives. The education process is indeed a universal problem experienced by every nation, so that the implementation of education will be influenced by various facilities, culture, situation and condition of the nation (Abdi Ridwanda dan Faridha Nurhayati. 2013)

Special education (PLB), as a form of education that specifically handles children with special needs as formal objects and material from various types of disorders including mentally retarded children, continuously strives to improve service as well as possible. However, As citizens, mentally retarded children have the same rights to get education (Yuniar Indah Utari dan Nanik Indahwati. 2015). Teaching for children with special needs is obtained from school, one school that accepts children with special needs is Special Schools (SLB). Extraordinary school (SLB) is a place of education and also teaching provided for those with special needs.

Extraordinary school (SLB) prepared as an educational institution to handle and provide educational services specifically for people with special needs (luh made suriwati, desak putu eka nilakusmawati, dan iwayan sumarjaya. 2014). Based on the above opinion can be concluded, that motor learning for the mentally retarded is having benefits is fine motor learning for the mentally retarded will optimize the movement of muscles in fine motor impairment moderate so that mentally retarded children are able to solve some problems related to fine motoric in their daily lives as in the case of holding, squeeze, holding and others without relying on others and being independent (Imroatus Solichah dan Siti Mahmudah. 2016).

Mentally disabled children need special attention and services to overcome the problems they experience (Dina Mustawati Maftuha dan Edy Rianto. 2014). Of the factors that occur in mild mental retardation children require activities related to self and physical health, one of them with exercises that can improve movement skills through locomotor basic motion, non locomotor, and manipulative (Wahyu 
Ardiyansyah dan Abdul Rachman Syam Tuasikal. 2016). Mild mental retardation children have difficulty understanding things that are abstract, have low intellectual intelligence, lack of concentration and limitations in adjusting to the social environment (Nur Khamidah. 2016)

Non-locomotor movement is an activity that moves body members on its axis and the actor does not move places. Non-locomotor forms of motion, namely avoiding, stretch the muscles, rotate and spin, swinging legs, depend, interesting, and the last is pushing (Yulingga Nanda Hanief dan Sugito. 2015). From the expert opinion and the observations that the researchers did, we can conclude that the nonlocomotor motion is a movement that moves very little from the support area. The point here is that there is no place to move just done at the fulcrum such as stretching (static).

Children who have leadership spirit usually have breakthroughs (innovations) that are good to make changes continuously in the reference to be better in accordance with the times. Innovation is related to the activity of creating change and improvement (Fimce, Agus, dan Jacky. 2015). Leader characteristics include the innate potential possessed by the individual concerned, educational and socio-economic background, and leadership skills (Ritania Hapsari dan Hastaning Sakti. 2016). A leader must have breakthroughs (innovation) that are good to make changes continuously in the reference to be better in accordance with the times. Innovation is related to the activity of creating change and improvement. Change which means also introducing something new by replacing the old one to a better thing (Fimce Masambe, Agus, dan Jacky Sumarauw. 2015).

Other forms of leadership state that there are many similarities servant leadership with transformational leadership. The similarity is related to characteristics vision, influence, credibility, trust, dan service. The forms consist of:Altruistic calling, Emotional healing, wisdom, Persuasive mapping, Organizational stewardship, humility, Vision, Service. (Seger Handoyo. 2010).

a. Altruistic callingdescribes the strong desire of leaders to make a positive difference in the lives of others and put the interests of others above their own interests and will work hard to meet the needs of their subordinates. 
b. Emotional healing describe a leader's commitment and his skills to improve and restore subordinate spirit from trauma or suffering.

c. wisdom describe leaders who are easy to catch signs in their environment, so understanding the situation and understanding the implications of the situation.

d. Persuasive mappingdescribes the extent to which a leader has the skills to map problems and conceptualize the highest possibilities for occurrence and urge someone to do something when articulating opportunities.

e. Organizational stewardshipdescribes the extent to which leaders prepare organizations to make positive contributions to their environment through community service programs and community development and encourage higher education as a community.

f. humility describe the leader's humility, and placing and respecting other people's achievements more than their own achievements.

g. Vision describes the extent to which leaders seek the commitment of all members of the organization to a shared vision by inviting members to determine the direction of the future of the organization and writing a shared vision.

h. Service describes the extent to which service is seen as the core of leadership and leaders demonstrate their service behavior to subordinates.

Based on the results of observations made at extraordinary schools Perwari Padang researchers identified the low ability of non-locomotor motion which resulted in a lack of leadership spirit in retarded children. This can be seen in the eyes of learning physical education through warming up activities. For this reason, the researcher wants to do research on Increasing Non-Lokomotor Motion Through Instructional Leadership Method on Retarded Students. The purpose of this study is to determine the level of leadership possessed by retarded children through non-locomotor activity in physical education learning eyes, as well as evaluating the effectiveness of extension activities on the level of leadership in retarded children. 


\section{METHOD}

The type of research used in this study is qualitative research, with data collection methods using interviews and observations. The application of the researcher collects retarded children and then gives direction regarding the implementation of the correct heating movement which starts from head to foot (raise your head up, Push the head down, push your head to the right and left, turn right and left, the right shoulder is bent to the left, the left shoulder is bent right, the right hand is brought to the left, left elbow pressed, the same movement only hands are reversed, the right hand is brought back, the elbow is pressed with the left hand, the same movement only hands are reversed, hands pressed together, pushed up, hands pressed together, pushed up right, hands pressed together, pushed up the left finger and upper arm, hands pressed together, pushed to the front of the finger and upper arm, hands pressed together, pushed back, the waist is pushed $2 \mathrm{x}$ and left right $2 \mathrm{x}$, waist rotated right, right foot bent, left leg straightened to the side, the same movement is just behind the legs, right foot bent, left foot straightened back, the same movement is just behind the legs, feet lifted back, feet lifted to the side, sitting position, the thigh is pushed down on the supine position, legs bent one, body straightened). After giving directions about the correct relaxation movement, then pointing out one of the mentally retarded children to lead his colleagues to do static stretching. This research was conducted on July 20 - September 252018 at the Special School Padang Perwari, Sumatera Barat. In addition, the interview and documentation process is also carried out when collecting data. The informant for this study was chosen for several reasons. The informants used were taken in need consisting of 3 informants who were teachers who taught at the extraordinary Padang Perwari school. Objects in this study amounted to 30 students who are children with special needs (retarded) in the extraordinary school Perwari Padang. The data collection techniques and tools use the observation method, interviews and documentation. Data analysis techniques in this study are more of a description of the results of observations, interviews and documentation. The data that has been obtained will be analyzed qualitatively and described in descriptive form (Patton, 2001:103). Data analysis is "the process of arranging data sequences, organizing 
them into a pattern, basic categories and descriptions". The data analysis technique used in this study is to use steps as stated by Burhan Bungin (2003: 70), that is as follows:

1. data collection

2. data reduction

3. Display data

4. conclution drawing and verification

Research instrument:

a. raise your head up

b. Push the head down

c. Push your head right and left

d. Look right and left

e. The right shoulder is bent to the left

f. The left shoulder is bent to the right

g. The right hand is brought to the left, left elbow pressed

h. The same movement is only a hand reversed

i. The right hand is brought back, the elbow is pressed with the left hand

j. The same movement is only a hand reversed

k. Hand held together, pushed up

1. hands pressed together, pushed up right

$\mathrm{m}$. hands pressed together, pushed up the left finger and upper arm

n. hands pressed together, pushed to the front of the finger and upper arm

o. hands pressed together, pushed back

p. the waist is pushed $2 \mathrm{x}$ and left right $2 \mathrm{x}$

q. waist rotated right

r. right foot bent, left leg straightened to the side

s. the same movement is just behind the legs

t. right foot bent, left foot straightened back

u. the same movement is just behind the legs

v. feet lifted back

w. feet lifted to the side 
x. Sitting position, both feet are placed on the palm, thighs pushed down

y. supine position, legs bent one, body straightened

\section{Results and Discussion}

\section{Results}

Improved non-locomotor motion using this leadership method researchers used static heating, so researchers collect retarded children then give direction or show the right movements, then the researcher appoints one of the retarded children to guide his colleagues to warm up. so before the student warms up the researcher gives instructions or directions to warm up right from the top of the head to the feet then then instructs the retarded child to do the monitoring. From the observations and the results of the interviews that we conducted that the retarded children actually have good leadership because they are able to give command or lead their colleagues well even though there are still a few deficiencies.

In fact, humans have their respective weaknesses and shortcomings, so in the application of learning methods we must look at the situation and conditions in the field how to use the effective learning process so that students are able to capture what we say. Do not equate the learning process of normal children and those who lack. so teaching children who have disadvantages like retarded children we must pay more attention because having low learning abilities that are not the same as normal children usually.

In accordance with the results of interviews and observations that the researchers obtained in the field that the children who were in school were exceptional especially the retarded child in the learning process he saw first then he could do. From the results of interviews and observations made researchers use Instructional Leadership methods to improve non-locomotor movements in retarded children. but before students do a non-locomotor movement in the form of static heating researchers give a first example of good static warming then the students do and appoint one of the students to help their colleagues to do static heating. 
After giving an example then the participants make a non-locomotor (stretching) movement that is done better compared before giving an example of the movement, and make students who command or lead their colleagues to warm up to be more confident and feel better compared to before so that the leadership that students have is better. So when learning provides examples, students make changes and make confident in leading their colleagues.

\section{Discussion}

From the results of research obtained in the field by the researcher, there was an increase in non-locomotor motion possessed by retarded children who were given using the Instructional Leadership method. Those who initially did the static warming movement just did when they were given the Instructional Leadership method to make their non-locomotor movements smoother compared to the Instructional Leadership method.. So the method in learning is very influential on the success of retarded children in the learning process, because of the weaknesses of retarded children who make it difficult to grasp the learning given by the teacher with the method is the right way for the learning process of the retarded child because of their lack.

Not all learning methods can be applied to the learning process of retarded children, we have to look at the situation and conditions in the field so that we can choose what kind of method will be given and the most important can make the retarded child interested and happy in the learning process. When the retarded child is interested and happy in doing the learning process then what we instruct will be heard a little and what we command will be done by mentally retarded children because they feel relaxed in the learning process

In the most prioritized learning process is how to make students when following the learning process can feel relaxed so that they will feel comfortable and want to follow the learning process well according to what we want. Moreover, the students the researchers gave were children who had low catching capacity, so the researcher had to give more attention to it by using the Instructional Leadership method that 
the researchers used in order to improve the non-locomotor motion which was good enough because of the increase in non-locomotor motion that was owned retarded child.

\section{CONCLUSION}

From the results and discussion above the researcher can conclude that the retarded child in the learning process he sees first and then he can do. From the results of the interviews and observations, the researchers used the Instructional Leadership method to improve the ability of non-locomotor movements of students with static heating movements. but before students do static heating we give a first example of good static heating then the students do and appoint one of the students to help their colleagues to do static heating. And as a result there is an increase in non-locomotor motion possessed by mentally retarded children to be more subtle after being given Instructional Leadership

\section{References}

Ardiyansyah, Wahyu dan Tuasikal, Abdul Rachman Syam. 2016. Modifikasi Permainan Lari Estafet Untuk Meningkatkan Gerak Dasar Manipulatif Anak Tunagrahita Ringan (Studi Pada Sdlb Merdeka Kecamatan Candi Kabupaten Sidoarjo). Surabaya: Universitas Negeri Surabaya Jurnal Pendidikan Olahraga dan Kesehatan Volume 04 Nomor 01 Tahun 2016, 177 - 184 ISSN : 2338-798X

Bungin, Burhan. (2003). Analisis Data Penelitian Kualitatif. Jakarta: PT Raja Grafindo Persada.

Gunarhadi dan Wardani, Esti. 2011. Upaya Peningkatan Akses Pendidikan Melalui Identifikasi Anak Berkebutuhan Khusus Di Kecamatan Sidoharjo Kabupaten Sragen. Surakarta: FKIP UNS JRR. Tahun 20. No.2, Desember 2011, 8-12

Handoyo, Seger. 2010. Pengukuran Servant Leadership Sebagai Alternatif Kepemimpinan Di Institusi Pendidikan Tinggi Pada Masa Perubahan Organisasi. Surabaya: Fakultas Psikologi, Universitas Airlangga, Surabaya 60286, Indonesia Makara, Sosial Humaniora, Vol. 14, No. 2, Desember 2010: 130-140

Hanief, Yulingga Nanda dan Sugito. 2015. Membentuk Gerak Dasar Pada Siswa Sekolah Dasar Melalui Permainan Tradisional. Kediri: Penjaskesrek Universitas Nusantara PGRI Kediri JURNAL SPORTIF .VOL. 1 NO. 1 NOVEMBER 2015

Hapsari, Ritania dan Sakti, Hastaning. 2016. Hubungan Antara Persepsi Terhadap Gaya Kepemimpinan Pelatih Dengan Efikasi Diri Pada Atlet Taekwondo Kota 
Semarang. Semarang: Universitas Diponegoro Jurnal Empati, April 2016, Volume 5(2), 373-377

Khamidah, Nur. 2016. Peningkatan Keterampilan Otomotif Tambal Ban Melalui Metode Latihan Pada Siswa Tunagrahita Ringan Kelas X Di Slb Negeri 1 Sleman. Yogyakarta: Universitas Negeri Yogyakarta Jurnal Pendidikan Khusus Edisi April Tahun 2016

Maftuha, Dina Mustawati dan Rianto, Edy. 2014. Permainan Gobak Sodor Modifikasi Terhadap Peningkatan Kemampuan Gerak Dasar Anak Tunagrahita Ringan. Surabaya: Universitas Negeri Surabaya

Masambe, Fimce, Agus, dan Sumarauw, Jacky. 2015. Pengaruh Gaya Kepemimpinan, Budaya Organisasi Dan Inovasi Pemimpin Terhadap Kinerja Karyawan Daihatsu Kharisma Manado. Manado: Universitas Sam Ratulangi Jurnal EMBA 939 Vol.3 No.3 Sept. 2015, Hal.939-949 ISSN 2303-11

Patton, M. Q. (2001). Qualitative Researchand Evaluation Methods (3rded.). Thousand Oaks, CA: Sage Publications, Inc.

Prastowo, Gurit dan Syam, Abdul Rachman. 2014. Pengaruh Metode Pembelajaran Part Practice Terhadap Hasil Belajar Shooting Bola Basket (Studi Pada Siswa Kelas Xi-Ips Sma Negeri 1 Cerme). Surabaya: Universitas Negeri Surabaya Jurnal Pendidikan Olahraga dan Kesehatan Volume 02 Nomor 03 Tahun 2014, 747 - 749 ISSN : 2338-798X

Ridwanda, Abdi dan Nurhayati, Faridha. 2013. Hubungan Antara Status Gizi Dengan Tingkat Kebugaran Jasmani Pada Siswi Smk Negeri 1 Surabaya Kelas X Tahun Ajaran 2012-2013. Surabaya: Universitas Negeri Surabaya Jurnal Pendidikan Olahraga dan Kesehatan Volume 01 Nomor 02 Tahun 2013, 291 - 295

Solichah, Imroatus dan Mahmudah, Siti. 2016. Kegiatan Menempel Kolase Sederhana Terhadap Kemampuan Motorik Halus Anak Tunagrahita Sedang Di Slb C. Surabaya: Universitas Negeri Surabaya Kegiatan Menempel Kolase Sederhana

Suriwati, Luh Made, Nilakusmawati, Desak Putu Eka, dan Sumarjaya, Iwayan. 2014. Efektivitas Pembelajaran Dengan Media Visual Untuk Meningkatkan Hasil Belajar Siswa Tuna Rungu Pokok Bahasan Pecahan Senilai. Bali: Universitas Udayana Seminar Nasional Matematika 2014, Universitas Udayana ISSN: 24069868

Utari, Yuniar Indah dan Indahwati, Nanik. 2015. Upaya Meningkatkan Gerak Dasar Lokomotor Anak Tunagrahita Ringan Melalui Permainan Tradisional (Pada SiswaSiswi Sekolah Dasar Luar Biasa Tunas Mulya Surabaya). Surabaya: Universitas Negeri Surabaya Jurnal Pendidikan Olahraga dan Kesehatan Volume 03 Nomor 02 Tahun 2015, 279 - 282 ISSN : 2338-798X 